(ISSN - 2752-7018)

VOLUME 02 ISSUE 01 Pages: 94-99

SJIF IMPACT FACTOR (2021: 5. 376)

OCLC - 1276789625 METADATA IF - 7.569

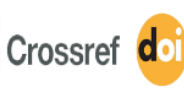

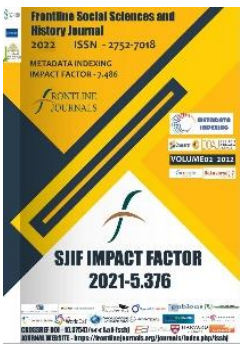

Journal Website: https://frontlinejournal s.org/journals/index.ph $\mathrm{p} /$ fsshj

Copyright: Original content from this work may be used under the terms of the creative commons attributes 4.0 licence.
Research Article

\section{THE SPECIFICATIONS OF STUDENT-CENTERED LANGUAGE CLASSROOM}

Submission Date: January 11, 2022, Accepted Date: January 20, 2022,

Published Date: January 31, 2022

Crossref doi: https://doi.org/10.37547/social-fsshj-02-01-12

Mahliyo Kukiboyeva

Senior lecturer, Independent researcher,Namangan State University, Uzbekistan,

\title{
Abstract
}

Current article outlines the peculiarities of application of learner-centered approach in teaching English as a foreign language. There specified advantages and disadvantages of using student-centered language instruction.

\section{KeYwords}

Student-centeredness, teacher-centeredness, learner autonomy, interaction, activities, group work, independent learning.

\section{INTRODUCTION}

It is universally proven that any kind of innovation or invention comes into being because of a need. Similarly, in terms of language teaching methods and approaches as soon as there 
(ISSN - 2752-7018)

VOLUME 02 ISSUE 01 Pages: 94-99

SJIF IMPACT FACTOR (2021: 5 • 376)

OCLC - 1276789625 METADATA IF - 7.569

appeared need to learn languages, people started to create various effective ways of learning and teaching foreign languages. Since then the history of language teaching and learning experienced diverse methods and approaches and this trend keeps on improving due to the extending needs for language education. This article is devoted to describe the main characteristics of studentcentered language pedagogy and possible number of advantages to satisfy actual needs in language learning and teaching in the level of higher education. Current article is based on a practical research of a visiting scholar at an American higher educational institution namely the University of Kansas.

\section{Materials and Methods}

In the history of foreign language teaching, teacher-centeredness in language classes has been preferable as an effective instruction mode for many years, but the student-centered approach to foreign language teaching based on modern methods is gaining popularity during the recent decades. One of the main features of a foreign language lesson where the teacher plays a central role is that the teacher's speech during the lesson lasts much longer than the time the students speak and communicate. At the same time, the student is mainly in the role of "listener" in the foreign language class, learners can only get acquainted with the language material provided by the teacher. The main advantage and characteristic of student-centered foreign language courses is that they take into account the learner's level of language skills, needs, interests, learning styles, basic knowledge, and gives freedom in language practise and acquisition [1]. In such foreign language classes, the role of the teacher is to facilitate the learning process. What needs to be clarified is the role of the teacher and the student in the foreign language lesson, which should not lead to the misconception that "the student is active, he takes on the role of teacher, and now the teacher is inactive, more in the role of a listener" [3].

Centuries-old traditions of foreign language teaching show that the teacher is the main worker and practitioner in the classroom, he selects, presents, reinforces, tests comprehension, asks questions, corrects mistakes, comments, concludes. In this method the teaching process has to be so inefficient, tedious, and cumbersome which does not allow language learners to take a creative, critical, analytical approach to the 
(ISSN - 2752-7018)

VOLUME 02 ISSUE 01 Pages: 94-99

SJIF IMPACT FACTOR (2021: 5 • 376)

OCLC - 1276789625 METADATA IF - 7.569

Crossref do

Publisher: Frontline Journals

learning process, and to share personal findings and conclusions.

Not only does teacher-centered foreign language teaching be a challenge for the teacher, but it also limits the opportunity of students, especially in the role of listener, to learn the language creatively and effectively through the application of language skills, collaboration, and practicing in authentic assignments.

In student-centered foreign language learning environment, learners are given the opportunity to discuss and negotiate with the teacher on the main topic, the types of exercises and assignments, the time allotted to them, the approach to assessment and the types of activities [4].

The most characteristic features of the studentcentered approach are that students are more active, working more in pairs, in small groups, responding to peers and evaluate their own responses, that students have more time to talk and communicate than the teacher, and students' personal opinions and choices are taken into account.

The main principles of a student-centered approach to foreign language teaching are:
- Students are responsible for their own learning processes

- The active participation and involvement of the student in the learning process is an important feature of language learning

- A sense of equality among students is a priority in the classroom, and it is important to ensure that learners are not divided into categories as active or inactive.

- The teacher is a facilitator and a source of information

- Learners need to learn to find solutions to their personal difficulties and problems in language learning

- Foreign language lessons should focus on the development of communication and speaking skills based on real-life language needs and social situations. [5]

The advantages of a student-centered approach to foreign language lessons are:

- Students work in small groups through the foreign language skill practise of communication and collaboration

- During the lesson, students become more interested and active in the process by interacting with each other 
(ISSN - 2752-7018)

VOLUME 02 ISSUE 01 Pages: 94-99

SJIF IMPACT FACTOR (2021: 5 • 376)

OCLC - 1276789625 METADATA IF - 7.569

Publisher: Frontline Journals

- Students are able to direct their learning process, ask questions and work independently on assignments

- Students are able to evaluate their own learning processes and others' speech by commenting and giving feedback

- Identify their own difficulties in the learning process and develop problem-solving skills

Each developed method or approach has a specific goal and outcome, is targeted at a specific environment and learner, and has specific advantages and disadvantages. The following disadvantages and challenges can be observed in student-centered foreign language lessons:

- Due to the predominance of student communication and teamwork, the learning process can be noisy, crowded, action-packed, and somewhat chaotic.

- Due to the importance of involving all students in the assignments, the teacher may have difficulty allocating time at different stages of the lesson due to the different pace of student work.

- Because the teacher did not provide detailed explanations and information on the completion of the assignments, some students may have difficulty completing the assignments and missing important elements.

- Teamwork can be tedious or difficult because some students prefer to work alone rather than in groups.

There are five main features of a student-centered foreign language classes:

1.

In a foreign language class, students work in a busy, noisy, dynamic, interactive process. In fact, the teacher is more burdened than the students, ie they select the content of the language material, discuss the exercises and assignments with the students, ensure everyone's active and equal participation, divide the time, give opinions and comments, give examples, encourage

2.

The teacher teaches students how to assimilate information, solve problems, analyze evidence, make predictions, and evaluate, rather than ready-made information. Figuratively speaking, they "do not give fish, but they teach how to fish." [2] 
(ISSN - 2752-7018)

VOLUME 02 ISSUE 01 Pages: 94-99

SJIF IMPACT FACTOR (2021: 5 • 376)

OCLC - 1276789625 METADATA IF - 7.569

Publisher: Frontline Journals

3. During the lesson, teachers encourage students to take an analytical approach to their learning process. They talk to students about what they are learning, what they are struggling with, and how to solve these problems. Students are taught to analyze and evaluate their own performance. The goal is to teach the learner to understand what he or she is and to choose the most appropriate method. The student is most responsible for his or her own learning process.

4.

Student-centered foreign language courses are motivating because they give the student freedom, choice, and self-control in the learning process. Teachers share with students the right to prioritize and manage the classroom, giving them the freedom and choice of assignments, timelines, deadlines, completion methods, and assessment criteria.

5. This approach emphasizes student collaboration. Teachers are active participants in the process, not outside observers. Students learn more effectively from each other and together, they develop rules and structures based on their own conclusions, and teachers encourage and motivate everyone to contribute. [7]

\section{Conclusion}

In summary, student-centered foreign language teaching focuses on student priorities, learning more, practicing and drawing personal conclusions, finding solutions to problems and difficulties in learning a foreign language, and collaboration. From the above, it can be said that this approach incorporates the features of several methods, such as

- Active learning

- Cooperative learning

- Task based language teaching

- Project-based language teaching

- Communicative language teaching

The most important task of a teacher is to organize foreign language lessons as effectively as possible, so that he or she can use a combination of different methods, depending on the needs of 
(ISSN - 2752-7018)

VOLUME 02 ISSUE 01 Pages: 94-99

SJIF IMPACT FACTOR (2021: 5 • 376)

OCLC - 1276789625 METADATA IF - 7.569

Publisher: Frontline Journals

the learners and the characteristics of language learning and teaching environment.

\section{REFERENCES}

1. Axmedova L. Общеевропейские компетенции владения иностранным языком: изучение, обучение, оценка» в образовательном процессе республики Узбекистан. https://journal.fledu.uz/wpcontent/uploads/sites/3/2019/04

2. Bolitho, $\mathrm{R}$ Teacher development training recourses for Uzbek Higher education language teachers, 2013

3. Richards. C. Communicative Language Teaching Today. Cambridge University Press, 2006

4. Sowden, C. Culture and the good teacher in the English language Classroom. ELT journal,2007 vol.61/4pp.304-310

5. Tudor I. Learner-centeredness as language education. Cambridge university press, Cambridge, 1996

6. Walters, V. Teacher-centered Versus Student-centered Instruction: A Descriptive Case Study. London: ASCD, 2011
7. Weimer, M. Learner-Centered Teaching: Five Key Changes to Practice. New York: John Wiley \& Sons, 2013.

8. www.britishcouncil.org/learnenglish

9. www.teachingenglish.org.uk 